Document de Recherche du Laboratoire d'Économie d'Orléans

Working Paper Series, Economic Research Department of the University of Orléans (LEO), France DR LEO 2021-2

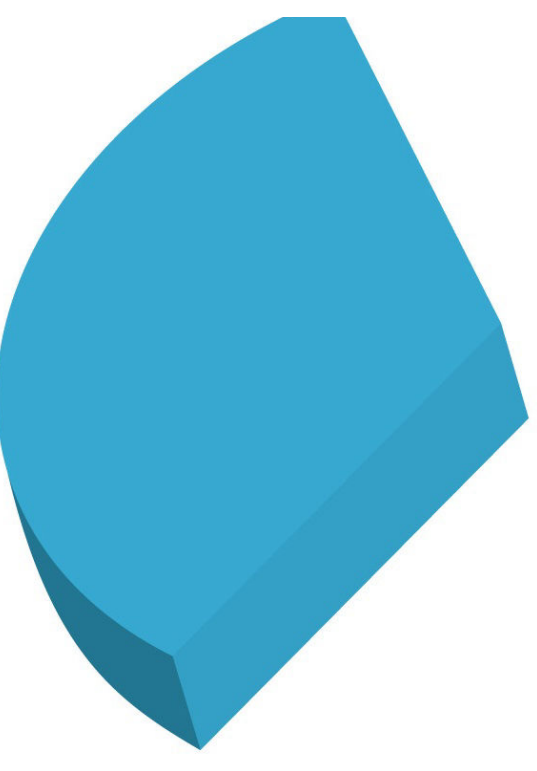

How can culture affect taxation? A postmaterialism value approach

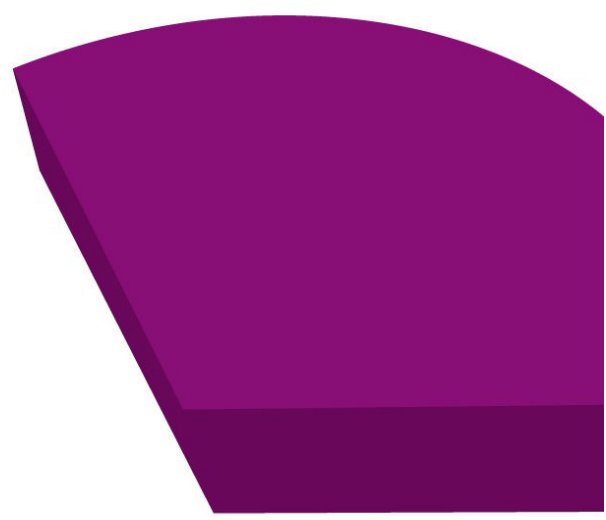

Nicolae-Bogdan IANC

Thierry BAUDASSÉ

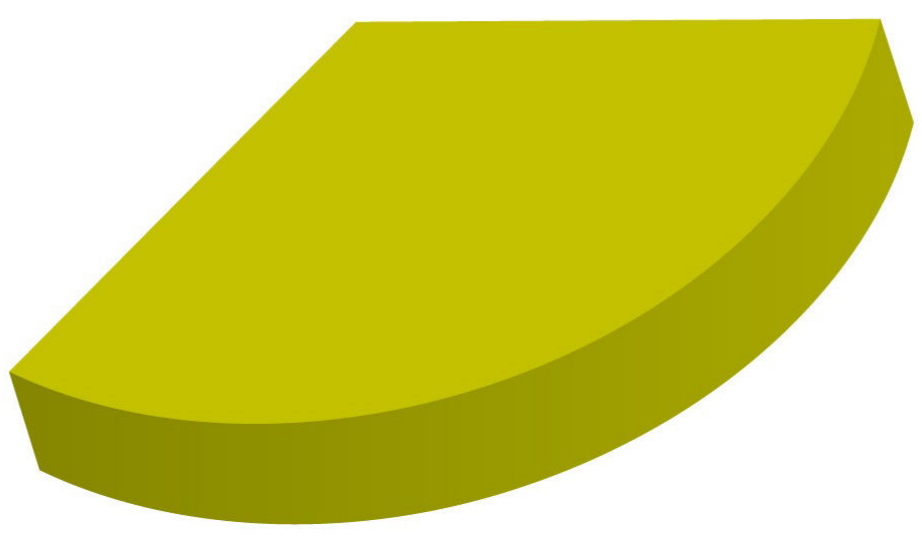

Mise en ligne / Online : 30/01/2021 


\title{
How can culture affect taxation? A postmaterialism value approach.
}

\author{
Nicolae-Bogdan Ianc * Thierry Baudassé ${ }^{\text {}} \quad$ T
}

\begin{abstract}
Direct tax revenues vary significantly, in the percentage of GDP, in selected countries. This difference is coming for various reasons. Our aim in this paper is to emphasize that there is a vital argumentation which is put forward to explain these variations, called cultural diversity. We employ a panel data with 46 selected countries and using the Materialist/Postmaterialist 12-item index; we highlight the impact of this postmaterialist index on direct tax revenues. Our study comprises six waves, and it includes the most recent dataset regarding culture dimension, namely World Values Survey Wave 7 (2017-2020). Moreover, we control for country characteristics and endogeneity issues. The results show that the degree of postmaterialism explains the level of direct tax revenues. The findings are robust when we include environmental taxes. These results highlight that cultural attitudes should be considered when studying the level of direct tax revenues and how culture dynamics impact taxation.
\end{abstract}

Keywords: culture, social capital, taxation

JEL classification: A13, H20, Z10.

${ }^{*} \mathrm{PhD}$ candidate, University of Orléans, LEO, FRE CNRS 2014, France and West University of Timisoara, East-European Center for Research in Economics and Business (ECREB), Romania, Email: nicolae-bogdan.ianc@univ-orleans.fr

${ }^{\dagger}$ University of Orléans, LEO FRE CNRS 2014, Email: thierry.baudasse@univ-orleans.fr

${ }^{\ddagger}$ We thank both the discussants and the participants in the Journées doctorales du Développement (Clermont-Ferrand, December 2017), INFER Workshop on Finance and Fiscal Policy (Bucharest, September 2018), Czech Economic Society and the Slovak Economic Association Meeting (Brno, September 2019) and $8^{\text {th }}$ UECE Conference on Economic and Financial Adjustments (Lisbon, December 2020) for their constructive comments and remarks. Special thanks to Mihai Mutascu, Camelia Turcu, Cosmin Enache and Alexandru Minea for their very helpful suggestions. Many thanks to my colleague PhD student El Moctar Laghlal. We also acknowledge the financial aid of "RTR (Réseau Thèmatique de Recherche) RISQUE" contract, the Laboratory of Economics in Orléans and the Faculty of Economics and Business Administration of West University in Timisoara. 


\section{Introduction}

Tax revenues are higher, as a percentage of GDP, in developed countries compared to developing ones. An 18 tax-to-GDP ratio for the latter versus 37.9 tax-to-GDP ratios for the former during 1995-1997 is displayed by Tanzi and Zee (2000). De Paepe and Dickinson (2014) show the same path more recently, namely 34 tax-to-GDP rates for OECD countries and almost a half for developing countries. OECD preserves a 34.2 percentage of GDP for 2017, and it was maintained for 2018's estimations (OECD 2019). A higher difference is highlighted by Besley and Persson (2014), who mention that tax revenues in low-income countries lay between 10 and 20 per cent of GDP, while high-income countries collect taxes of around 40 per cent of GDP. Moreover, in developed countries, the higher the tax-toGDP ratio, the higher direct taxation is, compared to indirect taxation. Furthermore, Mahdavi (2008) argues that the tax-to-GDP ratio is increasing in developing countries where economic determinants such as the degree of openness or the level of urbanization expanded lately. Ebrill et al. (2001) claim that consumption taxes could be an alternative for direct taxes in order to raise revenues and to modernize the tax structure.

Direct taxation is characterized by the same direction like tax revenues as a whole, namely a lower tax base for developing countries, as Auriol and Warlters (2005) notice. They argue that developing countries face this situation because of higher fixed costs to swift from informal to the formal economy and they suggest that reducing market entry fees could stimulate the countries to widen the tax base but in a gradual manner. Direct taxes are preferred to indirect taxes (Martinez-Vazquez et al. 2011), as the direct-to-indirect ratio is higher in developed countries than in developing ones. An IMF work (Cottarelli 2011) displays that overall income tax (i.e., direct taxation) represents 13 per cent of GDP in OECD countries, comparing to 3.5 per cent in low-income countries, 5 per cent in lowermiddle-income countries and 5.4 in upper-middle-income countries. 
One can notice that several countries shift their taxation from direct to indirect one, and this movement is more pronounced for developed countries than for developing ones. Loretz (2008) illustrates that governments in OECD economies tend to rely less on corporate taxation, which moves together with personal income tax, so they raise the consumption taxation in order to compensate. Analyzing corporate taxation in OECD countries, Clausing (2007) discovers a non-linear relation between corporate tax rates and revenues. Moreover, the revenue-maximizing rate is decreasing with the integration of a country into the world economy. Slemrod (2004) mentions that corporate tax rates are decreasing because of, inter alia, international competition. Mourre (2013) shows that shifting taxation from direct to indirect taxes in EU members is welcome in some circumstances. The advantage is that labour tax rates are decreasing, so economic growth is better achieved. All these studies show that developed countries reduce direct taxation rates which stimulate direct tax revenues but, as Cottarelli (2011) displays, the difference between direct taxation, as a share of GDP, in developed and developing countries still remains considerable.

Indirect taxation to GDP ratio indicates a value of 10 per cent for both developing and industrialized countries (Tanzi and Zee 2000). So direct taxation is the one which disrupts between developed and developing countries. We can see in the lower chart (Figure 1) that the values for direct tax revenues, in the percentage of GDP, vary significantly in selected countries. This difference is coming for various reasons. Several works are put forward to explain them. Alm et al. (1992) mention that people pay taxes because they value the public services they finance and Dhami and Al-Nowaihi (2007) show in a behaviour model why citizens are obeying tax rules. Evidence from multicultural European countries exhibits that higher legitimacy for political institutions shapes attitudes toward paying taxes (Torgler and Schneider 2007).

Our aim in this paper is to emphasize that there is another important argumen- 
Figure 1: Direct taxation as a percentage of GDP

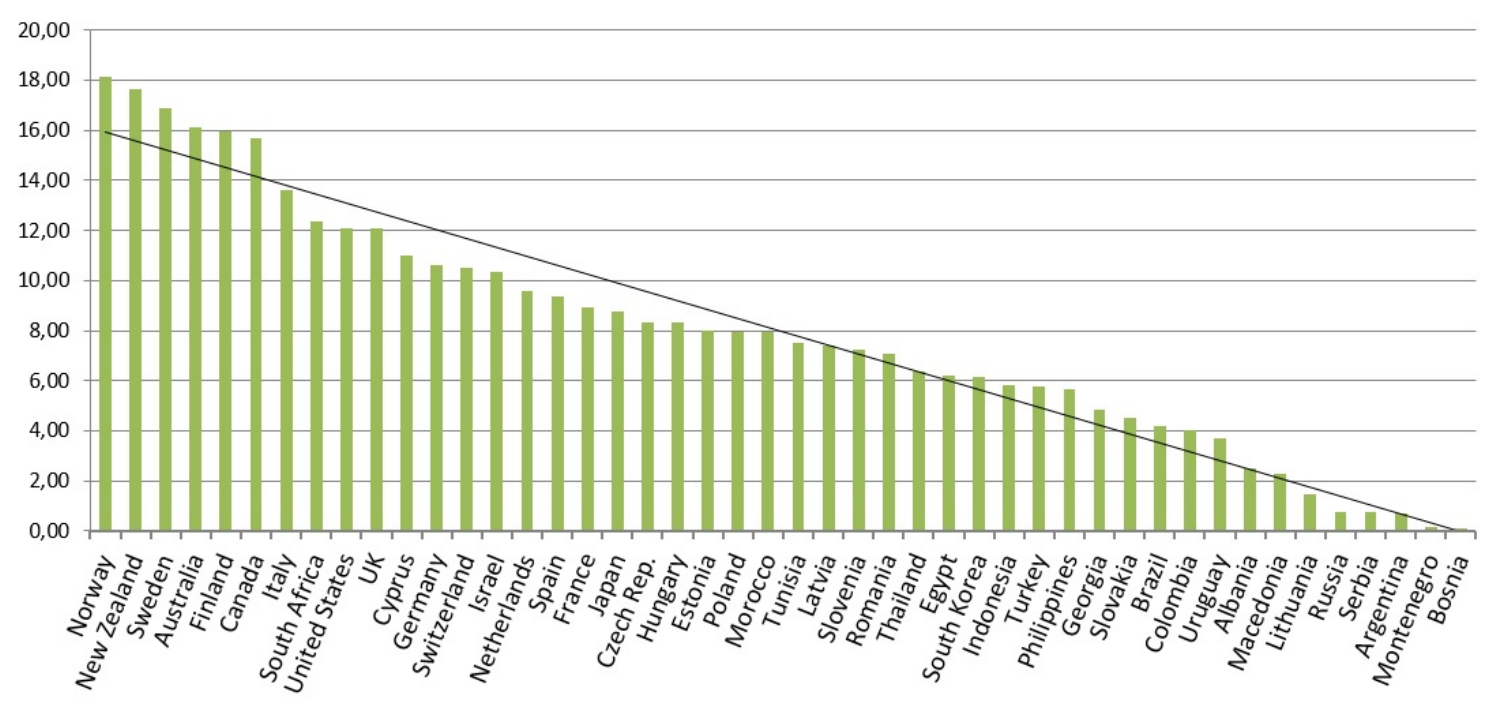

Source: World Bank (average from 1990 to 2020)

tation which is put forward to explain these variations shown in Figure 1, called cultural diversity. Culture impacts several economics outcomes as well, as the literature shows (La Porta et al. 1997, Guiso et al. 2004, 2006). We consider a panel data with a heterogeneous set of 46 countries, both developed and developing ones, and we use culture, namely the degree of postmaterialism, that we present below, to explain the variation of direct tax revenues, as a percentage of GDP. Economists measure culture using data surveys (Alesina and Giuliano 2015). In our study, cultural attitude and direct taxation are put in relation by using a cultural measurement tool based on survey questions ${ }^{1}$. A country whose citizens are not earthly-minded and care more about non-materialistic values, such as improving environmental protection, self-expression, quality of life, freedom of speech or social equity is a postmaterialist country (Inglehart 1971, 1977, Inglehart and Welzel 2005).

\footnotetext{
${ }^{1}$ The World Values Survey is the most commonly used tool for cross-country comparison (Alesina and Giuliano 2015).
} 
The "postmaterialism" question has been firstly raised by Ronald F. Inglehart ${ }^{2}$. So, the tax burden is less important for citizens in postmaterialist countries and higher tax revenues to GDP ratio is then justified.

Within the World Values Survey, there is a form called Materialist/Postmaterialist 12-item index ${ }^{3}$, which is the most relevant at measuring the degree of postmaterialism, according to its questions' design. Figure 2 illustrates each country's score on the postmaterialism scale. We use Sweden such as benchmark ${ }^{4}$, so it corresponds to zero level, and lower values mean moderation in postmaterialism. As this chart describes, the postmaterialist perception appears most in the Scandinavian Peninsula, West Europe and North America. The utmost standard of living is the main characteristics of those developed countries. We can observe a low spread of postmaterialism among Central and Eastern European countries (CEE), African countries and Asian countries. To build this last chart, we use the average values for the six waves starting from 1990 to 2020. Moreover, 1990 is a new beginning for CEE countries, once they become transition economies. Most CEE countries are close to materialist concept (Guérot and Hunklinger 2019), meaning that they have affection for monetary and wealth possession, so the catching-up process needs more time to be achieved (Ranjbar et al. 2018). In general, survey questions are considered sensitive by the vast majority of respondents, so their answers could emphasize low accuracy (Cornesse et al. 2020). Moreover, the major political parties in developed countries, which encourage the postmaterialistic beliefs, find difficulties to implement those policies as both Erdos (2009) and Pharr and Putnam (2018) highlight.

\footnotetext{
${ }^{2}$ Ronald F. Inglehart (born September 5, 1934) is a political scientist at the University of Michigan and the Founding President of the World Values Survey.

${ }^{3}$ Ronald F. Inglehart proposed this index in 1977 (Inglehart 1977) in order to measure the degree of postmaterialism.

${ }^{4}$ Sweden has the highest degree of postmaterialism according to the Materialist/Postmaterialist 12-item index form.
} 
Figure 2: Materialist/Postmaterialist 12-item index

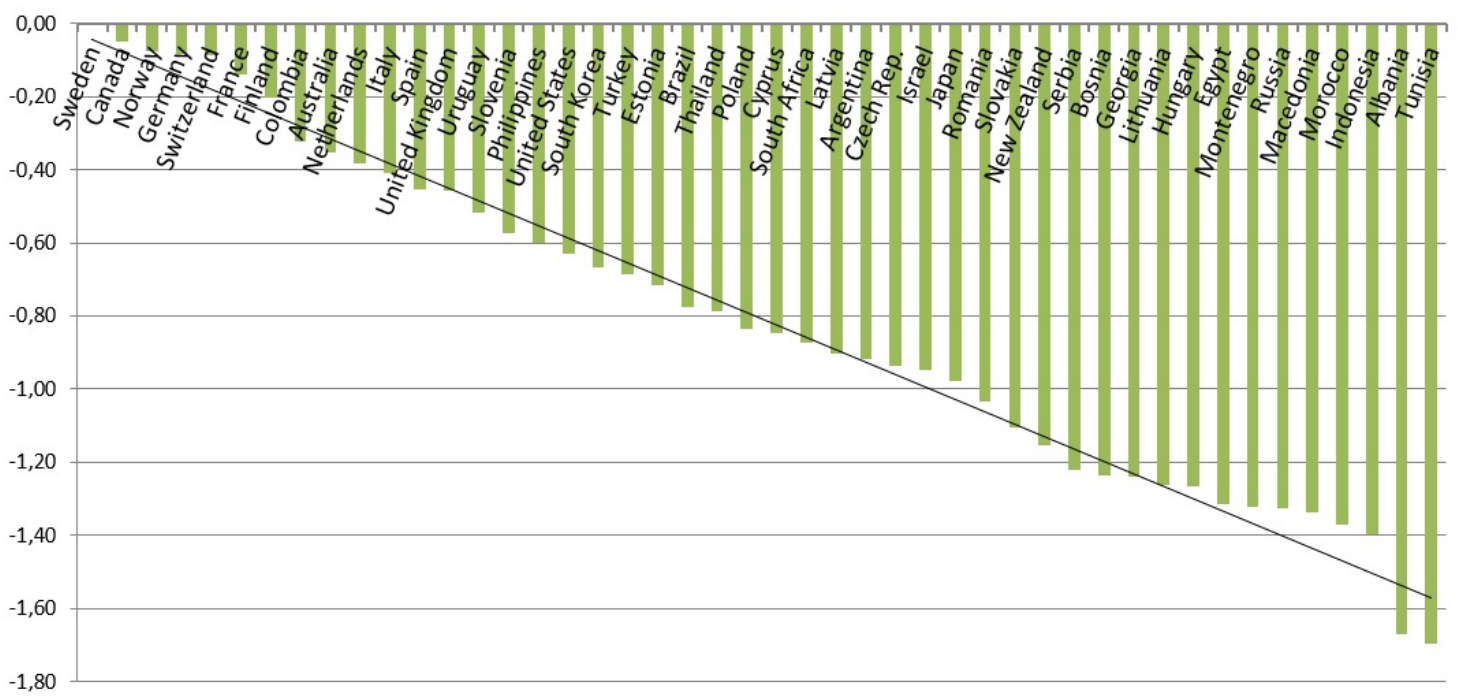

Source: World Values Survey (average values for six waves from 1990 to 2020).

Note: The actual values are diminished with the benchmark's (Sweden) score of 2.59.

Culture-focus research has become a critical analysis topic toward the end of the twentieth century. The beginning of the 1970s, it was noticed a real tendency toward postmaterialism in most developed countries both in Europe and North America. It was 25 years after World War II and a new generation appeared, which did not face the economic scarcity during the war or the immediately post-war period. The first who noticed this movement was the political scientist Ronald F. Inglehart in his works (Inglehart 1971, 1977). He detected very well in his publications an inter-generational change in the people's ideals mostly in industrial economies and then using a time-series approach, he made an empirical demonstration about this diversity. Moreover, he predicted that this change might have a significant long-term impact on the political behaviour of developed countries. Inglehart and Abramson (1999) showed that several West European countries exhibit a long-time trend from materialist to postmaterialist emphasis in the analysis along 25 years (from 1970 to 1994). Inglehart and Welzel (2005) tried to understand the causes of this trend 
better. They claimed that younger cohorts born in the fifth decade of the last century were no anymore interested by political and economic aims such as a higher GDP or price stability. Those younger cohorts switched their preferences to non-economic goals, such as environmental protection or freedom of speech. Moreover, the same authors claim that the cohort born after World War I was growing up in peace and welfare; being the first who no longer attended the materialist values. Delhey (2010) argues that happiness is coming with the movement from materialist to postmaterialist countries. Other facts related with this process are civil actions happening during those years, such as the riot of both students and workers in May 1968, France (Inglehart 2014) and the women's strike for equity in August 1970 in the US (Dow 2014).

The literature about of culture and taxation is not very rich for developing countries, because there is a lack of cultural data for them, so developed countries are prior to be studied (Alesina and Angeletos 2005). Rose (1985) finds that OECD countries were better noticed as being different in tax system because of the culture and Qari et al. (2012) claim that patriotic identification keeps mobile tax payers more attached to their home country within several OECD countries. Hence, the majority of works are referred to selected countries, both developed and developing ones. Tsakumis et al. (2007) claim that there are differences between cultural assumptions and the level of tax evasion in selected countries. Their article is the first who worked on the culture-tax evasion cause-effect based on the model of Hofstede ${ }^{5}$ (Geert and Jan 1991). In his work based on Hofstede's hypotheses over selected countries and after controlling economic development, Richardson (2008) obtains that the lower is the level of individualism, legal enforcement, trust in government and religiosity, the higher is the level of tax evasion. Daude et al. (2013) mention that

\footnotetext{
${ }^{5}$ Hofstede cultural dimensions theory is a framework for cross-cultural communication. Geert Hofstede (born 2 October 1928) is a Dutch social psychologist, former IBM employee, and Professor Emeritus of Organizational Anthropology and International Management at Maastricht University in the Netherlands, well known for his pioneering research on cross cultural groups and organizations.
} 
strengthening direct democratic elements helps increasing tax morale in emerging countries. Torgler (2006) highlights that religiosity raises tax morale. In this globalised era, Nerré (2008) identifies two mismatches of tax culture called tax culture shocks and tax culture lags. The latter was related to tax reforms, while the first was depicted in improper political measure. In a European context, Gulev et al. (2012) achieved strong results linking trust and confidence to higher tax revenues and higher tax progressively. Cábelková and Strielkowski (2013) suggest that the association between shared cultural values, on the one side, and tax revenues as a percentage of GDP, on the other side, proves to be statistically significant.

Our paper contributes to the literature with the following aspects. Primary, we use the most recent data set regarding culture dimension, namely the Wave 7: 2017$\mathbf{2 0 2 0}^{6}$, launched by the World Values Survey. Our work is, as far as we know, the first study which uses this newest wave for measuring the culture dimension concerning public policies.

Second, we work with the Materialist/Postmaterialist 12-item index, contrary to the literature. To the best of our knowledge, this is the first paper which employs this index to account for cultural variety with respect to taxation, and we choose it because of its comprehensiveness. Several works use the Post-materialist 4-item index form ${ }^{7}$, which presents four questions whereby two of them are related to materialist fundamentals, and the other two are relying on postmaterialist perception. For instance, Koenig and Wagener (2012) propose the usage of the 4-item index to illustrate that values and norms in OECD countries predict the tax structure. The 4-item index is employed within selected countries

\footnotetext{
${ }^{6}$ Data are available since July 2020, and they can be found here http://www.worldvaluessurvey.org/.

${ }^{7}$ The Post-materialist 4-item index form is the first index constructed by Ronald F. Inglehart (Inglehart 1971) in order to measure the degree of postmaterialism.
} 
by Jordaan et al. $(2016)^{8}$, who notice that postmaterialism is in a positive relationship with the stock markets. But Inglehart (1977) admits that the exploit of the 4-item index exhibits serious weakness (for measuring culture attitudes) and it is sensitive to short-term forces $^{9}$. The author confirms that the new-built items within this index are more stable, robust, and they exhibit a better vision of people's goals.

A third contribution is that our work concerns the impact of cultural attitudes on total direct taxation, as a share of GDP, in contrast with Koenig and Wagener (2012). Their analysis performs the tax structure, namely the corporate to personal tax revenues ratio. A distinction between our paper and Cábelková and Strielkowski (2013) is that the latter use total tax revenues as a percentage of GDP and blossom a model adopting the Hofstede's cultural dimension, in apparent contrast with our postmaterialist model approach.

We follow a different approach and open up new research avenues regarding the closest works to ours (Koenig and Wagener 2012, Cábelková and Strielkowski 2013, Jordaan et al. 2016). In our research, we employ the latest postmaterialist index within a higher number of selected countries (46). Our data-set covers a more recent period within we can capture better the tendency toward postmaterialism ${ }^{10}$. We show that values and beliefs, namely the idea of postmaterialism, point out the difference between direct tax revenues

\footnotetext{
${ }^{8}$ Jordaan et al. (2016) claim that data in their analysis covers three decades, namely 1980s, 1990s and 2000s.

${ }^{9}$ For example, Inglehart (1977) exhibits an item concerning the fight against rising prices. Higher inflation during those years could have biased the answers because high priority to this item would be linked to a current issue and not to a fundamental value.

${ }^{10}$ Although Alesina and Giuliano (2015) posit that values and beliefs in former European communist countries converge slowly to Western ones, Poland, a post-communist country, is considered as a highincome country by both OECD and the World Bank after a 20-year period of transition (Piatkowski 2013). Moreover, Poland is considered as a developed country since 2018 (Martin 2018).
} 
shown in Figure 1. More precisely, our results demonstrate that higher direct taxation, as a percentage of GDP, is found in countries where the tendency towards postmaterialism increases. Moreover, we add in our study tax on personal income, tax structure (i.e., direct to indirect ratio) and energy taxes. The results obtained hold, namely our robustness analysis is reliable.

This paper is organized as follows. Section 2 presents the research methodology, while Section 3 describes the data. Section 4 displays the results, and Section 5 presents the robustness analysis. Section 6 concludes.

\section{Methodology}

We aim to analyze the effects of cultural dimension, namely the degree of postmaterialism, on direct tax revenues, as a share of GDP. To do so, we employ a model using, among a large number of factors which affect direct taxation (Besley and Persson 2014, Mahdavi 2008), the Materialist/Postmaterialist 12-item index created by Inglehart. The following simple regression represents the core of our analysis:

$$
T_{i, t}=\beta_{0} X_{i, t}+\beta_{1} Y_{i, t}+\epsilon_{i, t}
$$

We use $i(i=1 . . N)$ to index the selected countries and $t$ for time. The model includes the following variables: $T_{i, t}$ represents the direct tax revenues, as percentage of GDP, $X_{i, t}$ stands for Materialist/Postmaterialist 12-item index of Inglehart and $Y_{i, t}$ stands for control variable such as public debt-to-GDP ratio, urban growth population rate and trade openness. The error term is represented by $\epsilon_{i, t}$.

First, we use pooled OLS regressions, and we include the control variables one 
by one. Second, we adopt a random-effect panel regression, in order to capture the timeinvariant components ${ }^{11}$, and the panel that we use is a balanced one. Moreover, it arises the endogeneity issue within this regression model, because its main idea is that direct taxation is higher due to a soaring score of the postmaterialist index. But does an augmented degree of postmaterialism conducts to raising tax revenues? To avoid biased results, we instrument the postmaterialist index, using the following equation, where $Z_{i, t}$ stands for the two instrumental variables chosen, namely female employers and female youth workers:

$$
X_{i, t}=\beta_{0} Z_{i, t}+\beta_{1} Y_{i, t}+\epsilon_{i, t}
$$

We address now to the tool which measures the postmaterialist index. Previous papers (Koenig and Wagener 2012, Jordaan et al. 2016) were related to the 4-item index imposed by the World Values Survey. This index is organized in two questions regarding materialist values and another two for postmaterialist ones. Admitting only materialist items gives you 1 point and accepting postmaterialist values awards you 3 points. The mixture yields you only 2 points.

Adopting a new index with 12 items was necessary because of the sensitivity of some items, like Inglehart himself (Inglehart 1977). Comparing to the 4-item index, the 12-item index is organized on three questions with 4-item answers for each question (see Appendix A). Those three questions allow six answers if we count a second answer option as well as (Inglehart 1977). So, scores range from zero (no Postmaterialist item is preferred) to five ${ }^{12}$ (all the Postmaterialist items are chosen). In total, we can eyeball six answers' options.

\footnotetext{
${ }^{11}$ Fixed effects model is used preferably with time variant effects, according to Torres-Reyna (2007).

${ }^{12}$ Notice that there are 5 Postmaterialist items (Nickens 2004).
} 


\section{Data}

In our analysis, we use a relatively moderate number of selected countries (46), because we are driven by the availability of data with regard to the degree of materialism. During the 1990 s, the waves were not very abundant of countries' answers, and in order to increase our number of observations, we use the average mean of the 1990-1994 and the 1995-1998 waves. We do so for the following waves, namely 1999-2004 and 2005-2009 one. The last two waves launched by the World Values Survey, called 2010-2014 and 2017-2020, were rich in answers, so we follow their genuine versions. The list of countries is found in Appendix $\mathrm{B}$, Table 1, as well as the mean values for the Materialist/Postmaterialist 12-item index and the direct taxation, as a share of GDP. Table 2 in Appendix B provides summary statistics descriptions, and Table 3 displays the data sources of our variables.

In order to better understand how the degree of postmaterialism is measured, we plot the scatter for our two main variables. In this respect, Figure 3 presents the correlation between the Materialist/Postmaterialist 12-item index and the direct tax revenues, as a percentage of GDP. The horizontal axis is represented by the mean values of the index used in Figure 2, and higher digit means more postmaterialist concentration. The vertical axis

depicts the mean values of direct tax revenues, as a share of GDP, displayed in Figure 1. The correlation coefficient is 0.35 , and it shows a positive relationship as we can see an upward trend. Higher index values associated with large direct tax revenues-to-GDP ratio are displayed in both Scandinavian and Western countries, while lower values are found in CEE, African and Asian countries.

\section{Empirical results}

We observe in Table 1, that direct tax revenues, as a dependent variable is positively im- 
Figure 3: Materialist/Postmaterialist 12-item index and direct tax revenues (\% GDP)

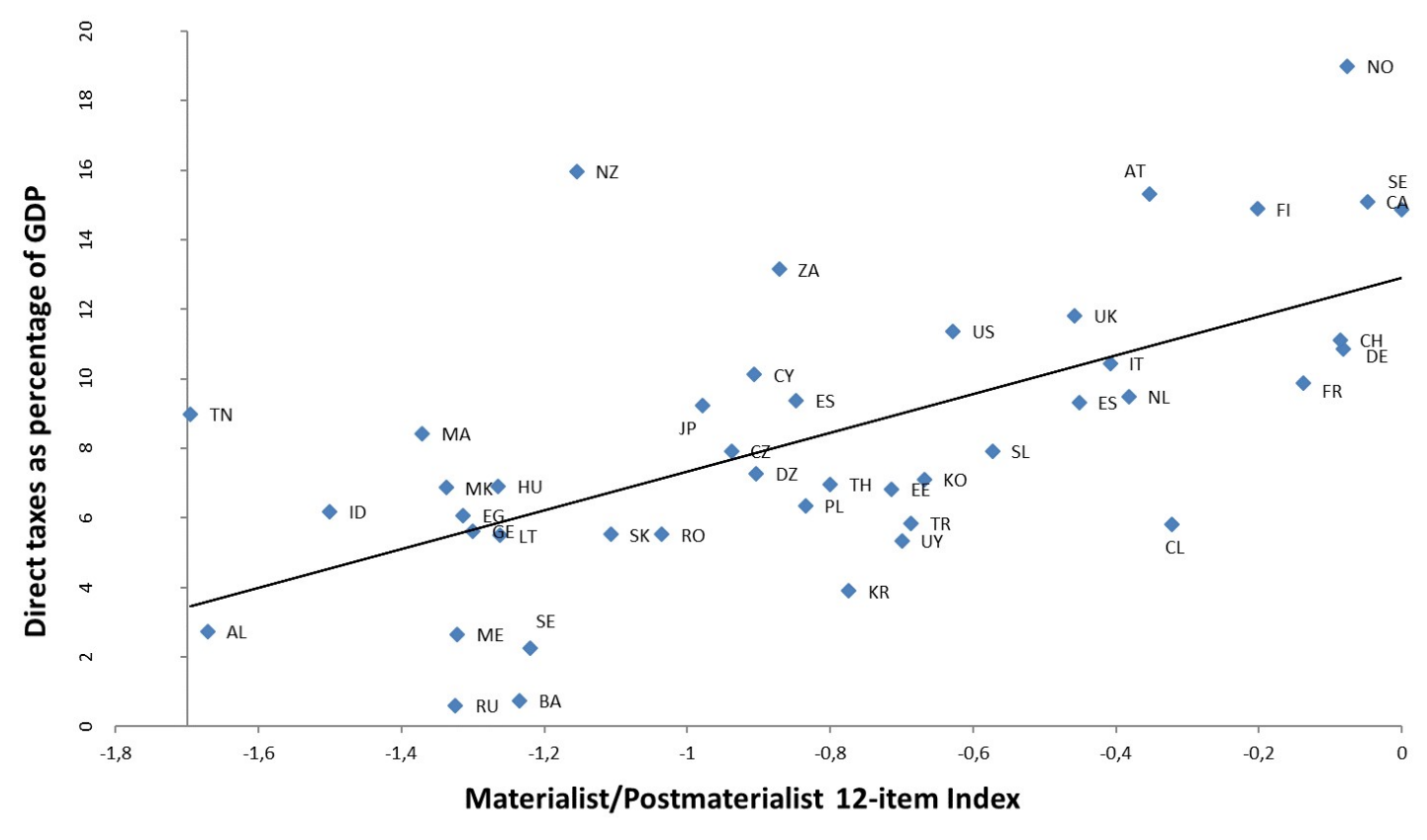

Source: World Values Survey and World Bank (average from 1990 to 2020).

Note: The actual values are diminished with the benchmark's (Sweden) score of 2.59.

pacted by the independent variable called Materialist/Postmaterialist 12-item index. This result corresponds to the idea that postmaterialistic countries tend to rely less on monetary or wealth accumulation and more on environmental protection or life quality. So, where countries undergo high wages, people can afford both paying taxes and having a decent standard of living without being hand-to-mouth. The results come along with Guiso et al. (2006), which posit the question if culture affects economic outcomes and show that direct taxes decrease with higher poverty population rate.

We include public debt as a control variable, because both countries which exert a high or a low degree of postmaterialism, use fiscal policy to pay their public debt, by either an increase in taxes or a cut in public spending (Monitor and Outlook 1989, Davig 
Table 1: The effects of postmaterialism on direct taxation

\begin{tabular}{|c|c|c|c|c|c|}
\hline Estimation method & OLS & OLS & OLS & $\mathrm{RE}$ & $\mathrm{RE}$ \\
\hline Postmat & $\begin{array}{c}4.29^{* * *} \\
(0.81)\end{array}$ & $\begin{array}{c}4.67^{* * *} \\
(0.88)\end{array}$ & $\begin{array}{c}4.67^{* * * *} \\
(0.88)\end{array}$ & $\begin{array}{c}2.84^{* * *} \\
(0.91)\end{array}$ & $\begin{array}{c}-1.08 \\
(4.78)\end{array}$ \\
\hline Public debt & $\begin{array}{l}0.00 \\
(0.01)\end{array}$ & $\begin{array}{l}0.00 \\
(0.01)\end{array}$ & $\begin{array}{l}0.01 \\
(0.01)\end{array}$ & $\begin{array}{l}0.01 \\
(0.01)\end{array}$ & $\begin{array}{l}0.01 \\
(0.01)\end{array}$ \\
\hline Urban growth pop & & $\begin{array}{c}0.98^{* * *} \\
(0.38)\end{array}$ & $\begin{array}{c}0.99^{* * *} \\
(0.38)\end{array}$ & $\begin{array}{c}0.58^{* * *} \\
(0.38)\end{array}$ & $\begin{array}{c}0.83^{* * *} \\
(0.38)\end{array}$ \\
\hline Trade openness & & & $\begin{array}{l}0.01 \\
(0.01)\end{array}$ & $\begin{array}{l}0.01 \\
(0.01)\end{array}$ & $\begin{array}{l}0.00 \\
(0.01)\end{array}$ \\
\hline Postmat $^{2}$ & & & & & $\begin{array}{l}1.09 \\
(1.30)\end{array}$ \\
\hline No. Obs & 117 & 99 & 99 & 99 & 99 \\
\hline Adj. $R^{2}$ & 0.20 & 0.26 & 0.26 & 0.38 & 0.40 \\
\hline
\end{tabular}

Standard errors in parentheses. Significance Codes, ${ }^{* * *}: 0.01{ }^{* *}: 0.05 ;^{*}: 0.1$.

2004, Nickel and Tudyka 2014). Besides, countries where direct tax revenues are higher, such as a large part of Western countries, are characterized by relatively higher public debt. Nevertheless, the effects of public debt on direct taxation are insignificant.

We control the urban population growth because it is a specific determinant in countries where tax-to-GDP revenues were increasing lately (Devereux et al. 2008). Moreover, Mahdavi (2008) claims that taxation is rising in developing countries where both urbanisation and trade openness surge. Higher trade openness was one of the determinants of increasing tax revenues (as a share of GDP) in OECD countries between 1960 and 1975, as Cameron (1978) mention. Urban population growth and trade openness exert positive effects on direct taxation, but the results for the latter are statistically insignificant.

We can eyeball until now a positive and significant relation between the explained variable and the postmaterialist index in all the five cases, except for the following case. In order to assess if the relationship between postmaterialism and taxation is characterised by 
non-linearity, we squared the index score and include it in our analysis, but the results are statistically insignificant.

Table 2: Panel Data Regression With Endogeneity Correction

\begin{tabular}{|c|c|c|c|}
\hline Estimation method & IV RE & IV RE & IV RE \\
\hline Postmat & $\begin{array}{c}12.75^{* * *} \\
(4.56)\end{array}$ & $\underset{(1.85)}{7.53^{* * *}}$ & $\begin{array}{c}8.16^{* * *} \\
(1.79)\end{array}$ \\
\hline Public debt & $\begin{array}{l}0.01 \\
(0.01)\end{array}$ & $\begin{array}{l}0.00 \\
(0.01)\end{array}$ & $\begin{array}{l}0.01 \\
(0.01)\end{array}$ \\
\hline Urban growth pop & $\begin{array}{l}0.98^{*} \\
(0.548)\end{array}$ & $\begin{array}{c}1.00^{* * *} \\
(0.42)\end{array}$ & $\begin{array}{c}1.00^{* * *} \\
(0.42)\end{array}$ \\
\hline Trade openness & $\begin{array}{l}0.01 \\
(0.01) \\
\end{array}$ & $\begin{array}{l}0.01 \\
(0.01) \\
\end{array}$ & $\begin{array}{l}0.01 \\
(0.01)\end{array}$ \\
\hline No. Obs & 89 & 99 & 99 \\
\hline Adj. $R^{2}$ & 0.29 & 0.30 & 0.30 \\
\hline No. instruments & 1 & 1 & 2 \\
\hline
\end{tabular}

Standard errors in parentheses. Significance Codes, $* * *: 0.01 ; * *: 0.05 ; *: 0.1$

Table 2 displays the random effects regression with endogeneity correction. We obtain positive and statistically significant results for both the postmaterialism index and the urban growth population. Positive, but statistically insignificant results are reported by both the public debt and trade openness. The results stand when regressing each instrument variable separately or both the instruments. The IV results are identical with those in the first equation (i.e., presented in Table 1) and the observations' number remains the same for the main regressions, namely pooled OLS and random effects in the first equation, and the IV random effects with two instruments.

Table 3 displays the first stage of the 2SLS model with instrumental variables, namely female employers and youth female workers. We can notice positive and significant results between, on the one hand, the postmaterialist index and, on the other hand, female 
employers and female youth workers. The first stage standard underidentification and weak instrument tests are suitable. Moreover, we fail to reject the null hypothesis of overidentification (i.e., the Sargan test) when using both the instruments, so those are valid.

Several aspects are put forward to explain these results. Higher direct tax revenues, as a percentage of GDP, in several countries (i.e., Scandinavian and Western ones), are the consequences of cultural diversity, namely respecting norms and values. Their citizens consider that these taxes will be redistributed correctly in the end. As Alm et al. (1992) show, people pay taxes, whereas the public services are better implemented. But some CEE countries are still close to materialist perception as Ranjbar et al. (2018) claim, so the catching-up process needs more years to be achieved.

The data collected for our work dates from 1990 to 2020, in contrast with Koenig and Wagener (2012), whose periods start from 1980 and finish in 2000, but the concept of postmaterialism is still present. Even after twenty years, the postmaterialist ideas and values are hard to be implemented by the political parties (Erdos 2009, Pharr and Putnam 2018). Only several countries, where GNP per capita is higher, can impose environmental taxes which are instead accepted by people than other types of taxes (Franzen 2003).

A policy implication concerning our results is that those countries, where the direct taxation is lower, should increase the quality of public services (Alm et al. 1992), modernize the tax structure (Ebrill et al. 2001), have tax reforms and improve the economic activity (Dreher 2005, Mahon Jr 2004). Other alternatives are environmental levies (Bovenberg and De Mooij 1994), but developed economies rather prefer those taxes, as (Franzen 2003) show. 
Table 3: First Stage of 2SLS

\begin{tabular}{|c|c|c|c|}
\hline & [1] & {$[2]$} & {$[3]$} \\
\hline Female employers & $\begin{array}{c}0.05^{* * *} \\
(0.03)\end{array}$ & & $\begin{array}{c}0.06^{* * *} \\
(0.03)\end{array}$ \\
\hline Youth female workers & & $\begin{array}{c}0.02^{* * *} \\
(0.00)\end{array}$ & $\begin{array}{c}0.01^{* * * *} \\
(0.00)\end{array}$ \\
\hline Public debt & $\begin{array}{l}0.00 \\
(0.00)\end{array}$ & $\begin{array}{l}0.00 \\
(0.00)\end{array}$ & $\begin{array}{l}0.00 \\
(0.00)\end{array}$ \\
\hline Urban growth pop & $\begin{array}{c}0.98^{* * *} \\
(0.48)\end{array}$ & $\begin{array}{l}0.00^{*} \\
(0.04)\end{array}$ & $\begin{array}{c}-0.02 \\
(0.04)\end{array}$ \\
\hline Trade openness & $\begin{array}{l}0.00 \\
(0.00)\end{array}$ & $\begin{array}{l}0.00 \\
(0.00)\end{array}$ & $\begin{array}{l}0.00 \\
(0.00)\end{array}$ \\
\hline $\begin{array}{l}\text { Underidentification test } \\
\text { (Anderson) }\end{array}$ & $5.66(0.01)$ & $27.23(0.00)$ & $26.17(0.00)$ \\
\hline $\begin{array}{l}\text { Weak identification test } \\
\text { (Cragg-Donald) }\end{array}$ & $5.7(0.01)$ & $35.54(0.00)$ & $17.08(0.00)$ \\
\hline $\begin{array}{l}\text { Overidentification test } \\
\text { (Sargan) }\end{array}$ & & & $0.18(0.67)$ \\
\hline No. Obs & 99 & 99 & 99 \\
\hline Adj. $R^{2}$ & 0.38 & 0.39 & 0.39 \\
\hline
\end{tabular}

Standard errors in parentheses. Significance Codes, *** : $0.01 ; * *$ : $0.05 ; *: 0.1$.

\section{Robustness check}

For robustness purpose, we add new variables, and we regress our model. First, we split the direct taxation in personal taxation and corporate taxation. The results are shown in Table 4, and they insinuate positive relationship between, on the one hand, the postmaterialist 
index, and, on the other hand, the personal taxation ${ }^{13}$. Both pooled OLS and random effects regressions are robust to our core analysis. Second, we add indirect taxation, and we analyse the direct-to-indirect taxation ratio ${ }^{14}$. The results stand when analyzing the tax structure, but the magnitude is smaller.

Table 4: The impact of postmaterialism on personal taxation and tax structure

\begin{tabular}{|c|c|c|c|c|}
\hline Estimation method & OLS & $\mathrm{RE}$ & OLS & $\mathrm{RE}$ \\
\hline Dependent variable & \multicolumn{2}{|c|}{ Personal taxation } & \multicolumn{2}{|c|}{ Direct/Indirect ratio } \\
\hline Postmat & $\begin{array}{c}3.74^{* * *} \\
(1.00)\end{array}$ & $\begin{array}{c}1.07^{* *} \\
(0.62)\end{array}$ & $\begin{array}{c}0.42^{* * * *} \\
(0.12)\end{array}$ & $\begin{array}{c}0.27^{* *} \\
(0.13)\end{array}$ \\
\hline Public debt & $\begin{array}{l}0.00 \\
(0.01)\end{array}$ & $\begin{array}{c}0.01^{* *} \\
(0.00)\end{array}$ & $\begin{array}{l}0.00 \\
(0.01)\end{array}$ & $\begin{array}{l}0.00 \\
(0.01)\end{array}$ \\
\hline Urban growth pop & $\begin{array}{l}0.01 \\
(0.45)\end{array}$ & $\begin{array}{l}0.31 \\
(0.27)\end{array}$ & $\begin{array}{c}0.17^{* * *} \\
(0.06)\end{array}$ & $\begin{array}{c}0.17^{* * *} \\
(0.06)\end{array}$ \\
\hline Trade openness & $\begin{array}{l}0.01 \\
(0.01)\end{array}$ & $\begin{array}{l}0.00 \\
(0.01)\end{array}$ & $\begin{array}{l}0.00 \\
(0.01)\end{array}$ & $\begin{array}{l}0.00 \\
(0.01)\end{array}$ \\
\hline No. Obs & 76 & 76 & 98 & 98 \\
\hline Adj. $R^{2}$ & 0.20 & 0.15 & 0.30 & 0.30 \\
\hline
\end{tabular}

Standard errors in parentheses. Significance Codes, ***: 0.01 ** $^{* *}$ $0.05 ; *: 0.1$.

Moreover, a relative higher postmaterialism degree emphasis on environmental protection (Franzen 2003, Dunlap and York 2008), so we introduce energy taxation in our work. The implicit tax rate on energy is the first variable included (i.e., related to tax energy), but it is related only for European countries, so a 23 -sample country is available ${ }^{15}$.

\footnotetext{
${ }^{13}$ Personal taxation and corporate taxation are taken from OECD Statistics, so our sample counts here 34 countries. We regress the corporate tax as well, but the results are non-statistically significant.

${ }^{14}$ Indirect taxation reports statistically insignificant results.

${ }^{15}$ We use the Eurostat database for the availability of this indicator. The implicit tax rate on energy is
} 
The second variable comprised in our analysis which counts the tax energy is the environmental taxes per capita ${ }^{16}$. The third indicator integrated into our study which treats tax energy is the OECD Environmental Policy Stringency Index ${ }^{17}$ (Botta and Koźluk 2014). Due to data availability, we include a 27 -countries sample concerning both the environmental taxes per capita and the environmental index. The results showed in Table 5 highlight that the postmaterialist index exerts positive effects on the implicit tax rate, environmental taxes per capita and the environmental index, either using the pooled OLS or the estimation of the random effects. The latter indicator is closer to environmental policy (Botta and Koźluk 2014) than to taxation (i.e., the fiscal policy), so we go further to account if any endogeneity issues arise between, on the one hand, the postmaterialist index, and, on the other hand, the environmental index. Table 9 in Appendix $\mathrm{C}$ shows the random effects regression with endogeneity correction. We use the same instrument variables presented above in our core analysis. Furthermore, Table 10 in Appendix C presents the first stage of the 2SLS model with the two instrumental variables which predict the values for the environmental index.

The above results confirm our main findings; namely, taxation is impacted by the degree of postmaterialism. The results hold when we divide direct taxation. Moreover, we add an implicit tax rate, the energy taxes per capita and the stringency environmentalrelated index and the results hold.

measured as EUR per tonne of oil equivalent. Eurostat defines it as the ratio between energy tax revenues and final energy consumption calculated for a calendar year. Energy tax revenues are measured in euro (deflated) and the final energy consumption as toe (tonnes of oil equivalent).

${ }^{16}$ Environmentally related tax revenue per inhabitant is calculated by the OECD Statistics in US-Dollar and is converted at 2010 purchasing power parities.

${ }^{17}$ The OECD Environmental Policy Stringency Index (EPS) is a country-specific and internationallycomparable measure of the stringency of environmental policy. Stringency is defined as the degree to which environmental policies put an explicit or implicit price on polluting or environmentally harmful behaviour (Botta and Koźluk 2014). The index ranges from 0 (not stringent) to 6 (highest degree of stringency). 
Table 5: The impact of postmaterialism on energy taxes

\begin{tabular}{ccccccc}
\hline Estimation method & OLS & RE & OLS & RE & OLS & RE \\
\hline Dependent variable & \multicolumn{2}{c}{ Implicit tax rate/energy } & Env. taxes/capita & \multicolumn{2}{c}{ Env. Index } \\
\hline \hline Postmat & $\begin{array}{c}0.50^{* * *} \\
(0.08)\end{array}$ & $\begin{array}{c}0.39^{* * *} \\
(0.11)\end{array}$ & $\begin{array}{c}1.27^{* * *} \\
(0.20)\end{array}$ & $\begin{array}{c}0.80^{* * *} \\
(0.24)\end{array}$ & $\begin{array}{c}0.94^{* * *} \\
(0.20)\end{array}$ & $\begin{array}{c}0.92^{* * *} \\
(0.21)\end{array}$ \\
Public debt & $0.00^{* * *}$ & $0.00^{* *}$ & 0.00 & 0.00 & $0.00^{* * *}$ & $0.00^{* * *}$ \\
& $(0.00)$ & $(0.00)$ & $(0.00)$ & $(0.01)$ & $(0.01)$ & $(0.00)$ \\
Urban growth pop & $0.18^{* * *}$ & $0.13^{* * *}$ & $-0.20^{* * *}$ & $-0.1^{*}$ & 0.08 & 0.09 \\
& $(0.04)$ & $(0.05)$ & $(0.10)$ & $(0.12)$ & $(0.09)$ & $(0.10)$ \\
Trade openness & 0.00 & 0.00 & 0.00 & $0.00^{* * *}$ & $0.01^{* * *}$ & $0.01^{* * *}$ \\
\hline No. Obs & $(0.00)$ & $(0.01)$ & $(0.01)$ & $(0.01)$ & $(0.00)$ & $(0.00)$ \\
\hline Adj. $\mathrm{R}^{2}$ & 46 & 46 & 62 & 62 & 66 & 66 \\
& 0.70 & 0.75 & 0.60 & 0.72 & 0.45 & 0.64
\end{tabular}

Standard errors in parentheses. Significance Codes, ${ }^{* * *}: 0.01 ; * *: 0.05 ;^{*}: 0.1$.

\section{Conclusion}

Direct tax revenues vary significantly, as a percentage of GDP, in selected countries. This difference is coming for various reasons. Our aim in this paper is to emphasize that there is a critical argumentation which is put forward to explain these variations, called cultural diversity.

We consider a panel data with a heterogeneous set of 46 countries, both developed and developing ones. We use culture, namely the degree of postmaterialism, to explain the variation of direct tax revenues, as a percentage of GDP. To do so, we use the form called Materialist/Postmaterialist 12-item index within the World Values Survey, proposed in 1977 by Ronald F. Inglehart, in order to measure the degree of postmaterialism.

The results show that direct tax revenues, as a dependent variable, are positively 
impacted by the degree of postmaterialist. These results correspond to the idea that the higher the score of the postmaterialist index is, the higher the direct tax revenues are. For tackling the endogeneity issues, we use two instrumental variables, namely female employers and female youth workers. Moreover, our results hold when we divide direct taxation, and we regress personal taxation. Further, we add an implicit tax rate, the energy taxes per capita and the stringency environmental-related index and the results hold. The implications of these results call for augmenting the quality of public services, modernizing the tax structure, having tax reforms and improving the economic activity. 


\section{Appendix A}

12-item Materialist/Postmaterialist Index questionnaire:

There is a lot of talk these days about what the aims of this country should be for the next ten years. On this card are listed some of the goals which different people would give top priority. Would you please say which one of these you, yourself, consider the most important? And which would be the next most important?

A. Maintaining a high level of economic growth.

B. Making sure this country has strong defense forces.

C. Seeing that people have more to say about how things are done at their jobs and in their communities.

D. Trying to make our cities and countryside more beautiful.

If you had to choose, which one of the things on this card would you say is most important? And which would be the next most important?

E. Maintaining order in the nation.

F. Giving people more say in important government decisions.

G. Fighting rising prices. 
H. Protecting freedom of speech.

Here is another list. In your opinion, which one of these is most important? And what would be the next most important?

I. A stable economy.

J. Progress toward a less impersonal and more humane society.

K. Progress toward a society in which ideas count more than money.

L. The fight against crime. 


\section{Appendix B}

Table 6: List of countries and mean values for the scores of the Materialist/Postmaterialist 12-item index and direct taxation, as \% GDP

\begin{tabular}{|c|c|c|c|c|c|}
\hline \multirow{2}{*}{ Country } & \multicolumn{2}{|c|}{ Variables } & \multirow{2}{*}{ Country } & \multicolumn{2}{|c|}{ Variables } \\
\hline & Postmaterialist index & Direct taxation & & Postmaterialist index & Direct taxation \\
\hline Albania & 0.86 & 2.52 & Morocco & 1.30 & 8.12 \\
\hline Algeria & 1.62 & 11.59 & Netherlands & 2.21 & 10.08 \\
\hline Australia & 2.23 & 16.30 & New Zealand & 1.68 & 17.80 \\
\hline Bosnia & 1.35 & 1.55 & North Macedonia & 1.19 & 4.80 \\
\hline Brazil & 1.94 & 3.90 & Norway & 2.51 & 17.56 \\
\hline Canada & 0,05 & 15.80 & Philippines & 2.06 & 5.61 \\
\hline Columbia & 2.23 & 4.64 & Poland & 1.85 & 7.83 \\
\hline Cyprus & 1.89 & 10.53 & Romania & 1.71 & 6.62 \\
\hline Czech Republic & 1.83 & 8.18 & Russia & 1.35 & 0.60 \\
\hline Egypt & 1.29 & 6.41 & Serbia & 1.56 & 5.56 \\
\hline Estonia & 1.87 & 7.86 & Slovakia & 1.78 & 7.66 \\
\hline Finland & 2.29 & 15.71 & Slovenia & 2.02 & 7.92 \\
\hline France & 2.45 & 9.60 & South Africa & 1.83 & 13.05 \\
\hline Georgia & 1.35 & 5.63 & South Korea & 1.99 & 7.03 \\
\hline Germany & 2.64 & 11.08 & Spain & 2.21 & 9.54 \\
\hline Hungary & 1.32 & 8.45 & Sweden & 2.59 & 16.67 \\
\hline Indonesia & 1.46 & 5.15 & Switzerland & 2.4 & 11.24 \\
\hline Israel & 1.64 & 10.32 & Thailand & 1.92 & 6.27 \\
\hline Italy & 2.18 & 10.45 & Tunisia & 1.14 & 7.81 \\
\hline Japan & 1.81 & 9.06 & Turkey & 2.07 & 5.84 \\
\hline Latvia & 1.69 & 7.26 & United Kingdom & 2.13 & 12.06 \\
\hline Lithuania & 1.33 & 6.2 & United States & 2.13 & 11.81 \\
\hline Montenegro & 1.24 & 0,12 & Uruguay & 2.07 & 4.03 \\
\hline
\end{tabular}


Table 7: Descriptive statistics

\begin{tabular}{|c|c|c|c|c|}
\hline Variables & Mean & Standard deviation & Minimum & Maximum \\
\hline Postmaterialist index & 1.86 & 0.45 & 0.80 & 3.04 \\
Direct taxation & 9.01 & 4.33 & 0.13 & 20.49 \\
Public debt & 53.86 & 32.72 & 4.83 & 237.00 \\
Urban Growth pop & 1.21 & 1.54 & -1.47 & 6.72 \\
Trade openness & 78.75 & 35.90 & 17.99 & 185 \\
Female employers & 2.23 & 1.21 & 0.33 & 7.62 \\
Youth female workers & 35.30 & 5.98 & 67.38 & 15.73 \\
Personal taxation & 6.76 & 0.10 & 16.32 & 3.66 \\
Indirect taxation & 10.32 & 3.51 & 18.55 & 3.06 \\
Implicit tax rate & 5.18 & 4.23 & 4.28 & 5.92 \\
Environment tax/capita & 6.18 & 0.99 & 2.51 & 7.41 \\
Environment index & 1.73 & 0.99 & 0.39 & 3.76 \\
\hline
\end{tabular}

Table 8: Data sources

\begin{tabular}{|c|c|c|}
\hline Variables & Description & Source \\
\hline Postmaterialist index & Materialist/Postmaterialist 12-item index & World Values Survey \\
Direct taxation & Taxes on income, profits and capital gains as \%GDP & OECD Statistics; World Bank \\
Public debt & Central government debt as \%GDP & World Bank \\
Urban Growth pop & Urban Population Growth, annual \% & World Bank \\
Trade openness & Trade, \% of GDP & World Bank \\
Female employers & Employers, female (\% of female employment) & World Bank \\
Youth Female workers & Employment to population ratio, ages 15-24, female (\%) & World Bank \\
Personal taxation & Taxes on income, profits and capital gains of individuals as \%GDP & OECD Statistics \\
Indirect taxation & Taxes on goods and services as \%GDP & OECD Statistics; World Bank \\
Implicit tax rate & Ln Implicit tax rate on energy, EUR per tonne of oil equivalent & Eurostat \\
Environment tax/capita & Ln Environmentally related tax revenue, per capita 2010 USD PPP & OECD Statistics \\
Environment index & Environmental Policy Stringency Index & OECD Statistics \\
\hline
\end{tabular}

\section{Appendix C}


Table 9: Endogeneity Correction for Environmental Stringency Index

\begin{tabular}{|c|c|c|c|}
\hline Estimation method & IV RE & IV RE & IV RE \\
\hline Postmat & $\begin{array}{l}1.53^{*} \\
(0.95)\end{array}$ & $\underset{(0.48)}{1.15^{* * *}}$ & $\begin{array}{c}1.22^{* * *} \\
(0.46)\end{array}$ \\
\hline Public debt & $\begin{array}{c}0.01^{* * *} \\
(0.00)\end{array}$ & $\begin{array}{c}0.00^{* * *} \\
(0.00)\end{array}$ & $\begin{array}{c}0.00^{* * *} \\
(0.00)\end{array}$ \\
\hline Urban growth pop & $\begin{array}{l}0.06 \\
(0.11)\end{array}$ & $\begin{array}{l}0.05 \\
(0.11)\end{array}$ & $\frac{1.00^{* * *}}{(0.42)}$ \\
\hline Trade openness & $\begin{array}{c}0.01^{* * *} \\
(0.00)\end{array}$ & $\begin{array}{c}0.00^{* * * *} \\
(0.01)\end{array}$ & $\begin{array}{c}0.01^{* * *} \\
(0.00)\end{array}$ \\
\hline No. Obs & 60 & 60 & 60 \\
\hline Adj. $R^{2}$ & 0.69 & 0.67 & 0.67 \\
\hline No. instruments & 1 & 1 & 2 \\
\hline
\end{tabular}

Standard errors in parentheses. Significance Codes, ${ }^{* * *}: 0.01 ; * *: 0.05 ; *: 0.1$. 
Table 10: First Stage of 2SLS

\begin{tabular}{lccc}
\hline & {$[1]$} & {$[2]$} & {$[3]$} \\
\hline Female employers & $0.07^{* * *}$ & & $0.05^{*}$ \\
& $(0.04)$ & & $(0.03)$ \\
Youth female workers & & $0.01^{* * *}$ & $0.01^{* * *}$ \\
& & $(0.00)$ & $(0.00)$ \\
Public debt & 0.00 & 0.00 & 0.00 \\
& $(0.00)$ & $(0.00)$ & $(0.00)$ \\
Urban growth pop & -0.05 & -0.07 & -0.07 \\
Trade & $(0.06)$ & $(0.05)$ & $(0.05)$ \\
& 0.00 & 0.00 & 0.00 \\
Underidentification test & $3.96(0.00)$ & $(0.00)$ & $(0.00)$ \\
(Anderson) & & & $14.01(0.00)$ \\
Weak identification test & $3.88(0.05)$ & $35.54(0.00)$ & $9.65(0.000)$ \\
(Cragg-Donald) & & & \\
Overidentification test & & & $0.17(0.69)$ \\
(Sargan) & & & \\
\hline \multicolumn{1}{c}{ No. Obs } & 60 & 60 & 0.67 \\
Adj. R ${ }^{2}$ & 0.69 & 0.67 &
\end{tabular}

Standard errors in parentheses. Significance Codes, *** : $0.01 ; * *$ : $0.05 ; *: 0.1$. 


\section{References}

Alesina, A. and Angeletos, G.-M. (2005). Fairness and redistribution. American Economic Review, 95(4):960-980.

Alesina, A. and Giuliano, P. (2015). Culture and institutions. Journal of Economic Literature, 53(4):898-944.

Alm, J., McClelland, G. H., and Schulze, W. D. (1992). Why do people pay taxes? Journal of Public Economics, 48(1):21-38.

Auriol, E. and Warlters, M. (2005). Taxation base in developing countries. Journal of Public Economics, 89(4):625-646.

Besley, T. and Persson, T. (2014). Why do developing countries tax so little? Journal of Economic Perspectives, 28(4):99-120.

Botta, E. and Koźluk, T. (2014). Measuring environmental policy stringency in OECD countries.

Bovenberg, A. L. and De Mooij, R. A. (1994). Environmental levies and distortionary taxation. The American Economic Review, 84(4):1085-1089.

Cábelková, I. and Strielkowski, W. (2013). Is the level of taxation a product of culture? a cultural economics approach. Society and Economy, 35(4):513-529.

Cameron, D. R. (1978). The expansion of the public economy: A comparative analysis. American Political Science Review, 72(4):1243-1261.

Clausing, K. A. (2007). Corporate tax revenues in oecd countries. International Tax and Public Finance, 14(2):115-133. 
Cornesse, C., Blom, A. G., Dutwin, D., Krosnick, J. A., De Leeuw, E. D., Legleye, S., Pasek, J., Pennay, D., Phillips, B., Sakshaug, J. W., et al. (2020). A review of conceptual approaches and empirical evidence on probability and nonprobability sample survey research. Journal of Survey Statistics and Methodology.

Cottarelli, C. (2011). Revenue mobilization in developing countries. International Monetary Fund, 8(2011):8-10.

Daude, C., Gutierrez, H., Melguizo, A., et al. (2013). What drives tax morale? a focus on emerging economies. Review of Public Economics, 207(4):9-40.

Davig, T. (2004). Regime-switching debt and taxation. Journal of Monetary Economics, $51(4): 837-859$.

De Paepe, G. and Dickinson, B. (2014). Tax revenues as a motor for sustainable development. Organisation of Economic Co-operation and Development (ed) Development co-operation report, pages $91-97$.

Delhey, J. (2010). From materialist to post-materialist happiness? national affluence and determinants of life satisfaction in cross-national perspective. Social Indicators Research, 97(1):65-84.

Devereux, M. P., Lockwood, B., and Redoano, M. (2008). Do countries compete over corporate tax rates? Journal of Public Economics, 92(5-6):1210-1235.

Dhami, S. and Al-Nowaihi, A. (2007). Why do people pay taxes? prospect theory versus expected utility theory. Journal of Economic Behavior \& Organization, 64(1):171-192.

Dow, B. J. (2014). Watching women's liberation, 1970: Feminism's pivotal year on the network news. University of Illinois Press.

Dreher, A. (2005). Does the imf influence fiscal and monetary policy? The Journal of Policy Reform, 8(3):225-238. 
Dunlap, R. E. and York, R. (2008). The globalization of environmental concern and the limits of the postmaterialist values explanation: Evidence from four multinational surveys. The Sociological Quarterly, 49(3):529-563.

Ebrill, L. P., Keen, M., Bodin, J.-P., Summers, V. P., et al. (2001). The modern VAT. International Monetary Fund.

Erdos, D. (2009). Postmaterialist social constituencies and political triggers: Explaining bill of rights genesis in internally stable, advanced democracies. Political Research Quarterly, 62(4):798-810.

Franzen, A. (2003). Environmental attitudes in international comparison: An analysis of the issp surveys 1993 and 2000. Social Science Quarterly, 84(2):297-308.

Geert, H. and Jan, H. G. (1991). Cultures and organizations: Software of the mind. McGrawHill USA.

Guérot, U. and Hunklinger, M. (2019). Old and New Cleavages in Polish Society. Edition Donau-Universität Krems.

Guiso, L., Sapienza, P., and Zingales, L. (2004). The role of social capital in financial development. American Economic Review, 94(3):526-556.

Guiso, L., Sapienza, P., and Zingales, L. (2006). Does culture affect economic outcomes? Journal of Economic Perspectives, 20(2):23-48.

Gulev, R. E., Lierse, H., et al. (2012). Cultural repercussions: Extending our knowledge about how values of trust and confidence influence tax structures within europe. Management, Knowledge and Learning, page 91.

Inglehart, M. R. (2014). Pushing the envelope-analyzing the impact of values. The civic culture transformed: from allegiant to assertive citizens. 
Inglehart, R. (1971). The silent revolution in europe: Intergenerational change in postindustrial societies. American Political Science Review, 65(4):991-1017.

Inglehart, R. (1977). The silent revolution: Changing values and political styles in advanced industrial society.

Inglehart, R. and Abramson, P. R. (1999). Measuring postmaterialism. American Political Science Review, 93(3):665-677.

Inglehart, R. and Welzel, C. (2005). Modernization, cultural change, and democracy: The human development sequence. Cambridge University Press.

Jordaan, J. A., Dima, B., and Golet, I. (2016). Do societal values influence financial development? new evidence on the effects of post materialism and institutions on stock markets. Journal of Economic Behavior \& Organization, 132:197-216.

Koenig, T. and Wagener, A. (2012). Culture and tax structures.

La Porta, R., Lopez-de Silanes, F., Shleifer, A., and Vishny, R. W. (1997). Legal determinants of external finance. The Journal of Finance, 52(3):1131-1150.

Loretz, S. (2008). Corporate taxation in the oecd in a wider context. Oxford Review of Economic Policy, 24(4):639-660.

Mahdavi, S. (2008). The level and composition of tax revenue in developing countries: Evidence from unbalanced panel data. International Review of Economics 85 Finance, 17(4):607-617.

Mahon Jr, J. E. (2004). Causes of tax reform in latin america, 1977-95. Latin American research review, pages 3-30.

Martin, K. (2018). Poland upgraded to developed market status by ftse russell. Financial Times, September, 24. 
Martinez-Vazquez, J., Vulovic, V., and Liu, Y. (2011). Direct versus indirect taxation: Trends, theory and economic significance. The Elgar Guide to Tax Systems, Edward Elgar Publishing, pages 37-92.

Monitor, F. and Outlook, R. E. (1989). Expenditure reductions in high-debt countries. Finance $\&$ Development.

Mourre, G. (2013). Tax policy challenges in eu countries: A few lessons from the 2012 commission tax reform report and the european semester. The Economic and Social Review, 44(4, Winter):489-510.

Nerré, B. (2008). Tax culture: A basic concept for tax politics. Economic Analysis and Policy, 38(1):153-167.

Nickel, C. and Tudyka, A. (2014). Fiscal stimulus in times of high debt: Reconsidering multipliers and twin deficits. Journal of Money, Credit and Banking, 46(7):1313-1344.

Nickens, B. H. (2004). Postmaterialism and Democracy: What Does the Postmaterialist Value Shift Mean for Democracy? PhD thesis, Virginia Tech.

OECD (2019). Revenue Statistics 2019.

Pharr, S. J. and Putnam, R. D. (2018). Disaffected democracies: What's troubling the trilateral countries? Princeton University Press.

Piatkowski, M. (2013). Poland's new golden age: shifting from Europe's periphery to its center. The World Bank.

Qari, S., Konrad, K. A., and Geys, B. (2012). Patriotism, taxation and international mobility. Public Choice, 151(3-4):695-717.

Ranjbar, O., Chang, T., Lee, C.-C., and Elmi, Z. M. (2018). Catching-up process in the transition countries. Economic Change and Restructuring, 51(3):249-278. 
Richardson, G. (2008). The relationship between culture and tax evasion across countries: Additional evidence and extensions. Journal of International Accounting, Auditing and Taxation, 17(2):67-78.

Rose, R. (1985). Maximizing tax revenue while minimizing political costs. Journal of Public Policy, 5(3):289-320.

Slemrod, J. (2004). Are corporate tax rates, or countries, converging? Journal of Public Economics, 88(6):1169-1186.

Tanzi, V. and Zee, H. (2000). Tax policy for emerging markets: Developing countries? IMF Working Paper No 35. Washington DC.

Torgler, B. (2006). The importance of faith: Tax morale and religiosity. Journal of Economic Behavior \& Organization, 61(1):81-109.

Torgler, B. and Schneider, F. (2007). What shapes attitudes toward paying taxes? evidence from multicultural european countries. Social Science Quarterly, 88(2):443-470.

Torres-Reyna, O. (2007). Panel data analysis fixed and random effects using stata (v. 4.2). Data 83 Statistical Services, Priceton University, pages 1-40.

Tsakumis, G. T., Curatola, A. P., and Porcano, T. M. (2007). The relation between national cultural dimensions and tax evasion. Journal of International Accounting, Auditing and Taxation, 16(2):131-147. 